\title{
Progesterone secretion and prostaglandin $F$ release in vitro by endometrial and luteal tissue of cyclic pigs
}

\author{
H. D. Guthrie and C. E. Rexroad, Jr \\ U.S. Department of Agriculture, Science and Education Administration, Agricultural Research, \\ Reproduction Laboratory, Beltsville, Maryland 20705, U.S.A.
}

\begin{abstract}
Summary. Blood and tissue were collected from 30 pigs on various days of the oestrous cycle to compare progesterone in peripheral plasma and progesterone release in vitro with prostaglandin (PG) $\mathrm{F}$ release in vitro by endometrial and luteal

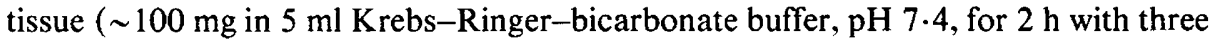
different incubation treatments). Plasma progesterone increased from Days 8 to 12 of the oestrous cycle $(25.1$ to $42.8 \mathrm{ng} / \mathrm{ml}, P<0.05)$ and decreased from Day 14 to $16(36.3$ to $5.9 \mathrm{ng} / \mathrm{ml}, P<0.05)$. Progesterone release in vitro at $37^{\circ} \mathrm{C}$ decreased from 18.0 to $2.7 \mathrm{ng} / \mathrm{mg}$ tissue from Days 8 to $16(P<0.05)$. Endometrial PGF release in vitro at $37^{\circ} \mathrm{C}$ increased slightly from Days 8 to 14 , then increased significantly from 43.7 to $103.5 \mathrm{ng} / 100 \mathrm{mg}$ tissue between Days 14 and 16 $(P<0.05)$. The rapid increase in endometrial PGF release coincided with the decrease in plasma progesterone. A small, non-significant increase in mean luteal PGF release was detected between Days 14 and 16. The results of this experiment did not suggest a critical role for luteal PGF- $2 \alpha$ in the process of luteolysis in the pig, but do provide indirect evidence for the involvement of endometrial PGF- $2 \alpha$ in luteolysis in the pig.
\end{abstract}

\section{Introduction}

Evidence has accumulated that implicates prostaglandin (PG) F-2 $\alpha$ as the uterine luteolysin in the pig. Increased plasma PGF in the utero-ovarian vein on Days 14-16 of the oestrous cycle (Gleeson, Thorburn \& Cox, 1974; Killian, Davis \& Day, 1976; Moeljono et al., 1977) corresponds to the stage of the cycle when the presence or absence of the uterus determines the regression or maintenance of the corpus luteum (Anderson, Butcher \& Melampy, 1963). Injections of PGF-2 $\alpha$ (Gleeson, 1974; Hallford, Wettemann, Turman \& Omtvedt, 1975) or its 16-aryloxy analogues (Guthrie \& Polge, 1976, 1978) caused luteolysis when corpora lutea were about 10 days old (Day 12 of the oestrous cycle or pregnancy).

Patek \& Watson (1976a) have proposed that luteal PGF-2 $\alpha$ synthesis in vivo might be involved in the process of luteolysis. They reported that luteal and endometrial PGF release in vitro was highest in tissues collected during the late luteal phase of the cycle. However, Guthrie, Rexroad \& Bolt (1978) found that corpora lutea and endometrium collected on Days 15-16 of the cycle did not synthesize significantly more PGF than those collected on Days 7-8.

The purpose of this experiment was to determine (1) whether endometrial and luteal PGF release in vitro increased between Days 8 and 18 of the oestrous cycle and (2) how endometrial and luteal PGF release in vitro relates to declining plasma progesterone and luteal progesterone release in vitro. 


\section{Materials and Methods}

\section{Tissue recovery and incubation}

Mature, crossbred pigs were assigned at random to be sampled (6/group) on Days 8, 12, 14, 16 or 18 of the oestrous cycle (Day $0=$ first day of oestrus). On the assigned day, a blood sample was collected from a jugular vein, and then each pig was anaesthetized with an intravenous injection of $1.2-1.5 \mathrm{~g}$ sodium thiopental $(33.3 \mathrm{mg} / \mathrm{ml}$ distilled water). A laparotomy was performed and the ovaries and uterus were excised. The ovaries and a $3-\mathrm{cm}$ long section from the middle of each uterine horn were carried to the laboratory in ice-cold $0.9 \%(\mathrm{w} / \mathrm{v}) \mathrm{NaCl}$ solution. Luteal and endometrial tissues were minced with scissors in ice-cold incubation medium (Krebs-Ringer-bicarbonate buffer, $\mathrm{pH} 7.4 ; 5 \mathrm{~mm}$-glucose, $10 \mathrm{~mm}$-sodium acetate and $1.3 \mu \mathrm{M}$-calcium). Minced luteal and endometrial tissues $(\sim 100 \mathrm{mg})$ were weighed into separate 25-ml Erlenmeyer flasks containing $5 \mathrm{ml}$ ice-cold incubation medium. Each tissue mince from each pig was incubated for $2 \mathrm{~h}$ with the following incubation treatments: (A) an atmosphere of air at $0^{\circ} \mathrm{C}$; (b) an atmosphere of $95 \% \mathrm{O}_{2}: 5 \% \mathrm{CO}_{2}$ at $37^{\circ} \mathrm{C}$; and (C) as for treatment $\mathrm{B}$ but indomethacin was added to the medium to make a concentration of $1.3 \times 10^{-4} \mathrm{M}$. Tissues were incubated at $37^{\circ} \mathrm{C}$ with indomethacin or at $0^{\circ} \mathrm{C}$ to determine whether accumulation of PGF or progesterone in the medium at $37^{\circ} \mathrm{C}$ was due, at least in part, to synthesis. After incubation, the medium was pipetted from each incubation flask and frozen at $-20^{\circ} \mathrm{C}$.

\section{Hormone assay}

Aliquots of the medium from the luteal tissue incubations were diluted 10 -fold with $0.01 \mathrm{M}$

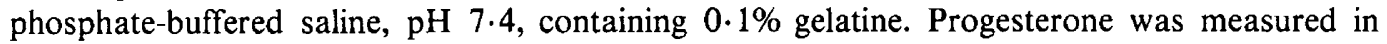
petroleum ether extracts of 10-100 $\mu$ blood plasma samples and the diluted medium by a previously validated radioimmunoassay (Guthrie, 1977; Guthrie et al., 1978). The antiserum (465/5 provided by Dr B. J. A. Furr, I.C.I., Macclesfield, England) was produced in a goat to an $11 \alpha$-progesterone-succinyl-bovine serum albumin conjugate. The antiserum was used at a dilution of $1: 5000$ and $100 \mu$ bound $60 \%$ of $0.01 \mu \mathrm{Ci}\left[1,2,6,7-{ }^{3} \mathrm{H}\right]$ progesterone in an incubation volume of $0.3 \mathrm{ml}$ per assay tube. Only $17 \alpha$-hydroxyprogesterone, pregnenolone and $17 \alpha$-hydroxypregnenolone had cross-reactivity of $>0.5 \%(1,3.4$ and $1.3 \%$, respectively). The progesterone standards were dissolved in distilled water and extracted along with the samples. The sensitivity of the assay was $15-20 \mathrm{pg} /$ tube at $90-95 \%$ binding, and the intra-assay and inter-assay coefficients of variability were 8.2 and $9.0 \%$, respectively.

Prostaglandin $\mathrm{F}$ was measured in aliquots of undiluted medium from the luteal and endometrial tissue incubations without extraction (Rexroad, 1978). The procedure was a double antibody radioimmunoassay with goat anti-PGF-2 $\alpha$ as the first antibody (10142-JCC-50, a gift of Dr K. T. Kirton, Upjohn Co., Kalamazoo) and rabbit anti-goat globulin (DJB $3 \times 1$, provided by Dr D. J. Bolt, this laboratory) as the second antibody. The antibody cross-reacted about $16 \%$ with PGF- $1 \alpha$ and $<0.016 \%$ with PG A-1, A-2, B-2, E-1 and E-2. Recovery of $0 \cdot 2-1.6 \mathrm{ng}$ PGF-2 $\alpha$ added to laboratory standards (see below) and assayed directly was $110 \pm$ $5 \%(n=14, r=0.99)$, and recovery from a pool of medium samples from pig luteal tissue incubations was $119 \pm 14 \%(n=15, r=0.92)$. The laboratory standards were supernatants of ovine uterine myometrium homogenates that had low (indomethacin-treated) or high (cycloheximide-treated) concentrations of PGF in relation to the standard curve. The laboratory standards were included in all assays and had intra- and inter-assay coefficients of variability of 8.6 and $14.1 \%$, respectively.

The hormone concentration of the incubation medium was analysed as a split-plot design; least squares analysis of variance was used. The whole-unit analysis consisted of the 5 days of the oestrous cycle when tissues were collected, and the sub-unit analysis was based on the 3 incubation treatments. Plasma progesterone concentrations were analysed as a completely 
randomized design; the 5 days of the cycle sampled for blood and tissue were used as the classification variable. Means from statistically significant treatment combinations were compared by Duncan's New Multiple Range Test. Linear correlation coefficients were calculated to determine the interrelationships among plasma progesterone, luteal medium progesterone and PGF and endometrial medium PGF concentrations after incubation at $37^{\circ} \mathrm{C}$. Partial correlation coefficients (Snedecor \& Cochran, 1967) were also calculated to determine whether these variables were correlated merely because of their common association with day of the cycle or whether there was a real relationship when the effect of day of the cycle was eliminated.

\section{Results}

Measurements of plasma progesterone and luteal progesterone release in vitro are shown in Table 1 . At $37^{\circ} \mathrm{C}$, luteal progesterone release decreased from the highest value on Day 8 to a value of approximately $50 \%$ by Day $14(P<0.05)$. In contrast, plasma progesterone increased from Day 8 to the highest value on Day $12(P<0.05)$; progesterone decreased markedly from Day 14 to $16(P<0.05)$. The decrease in luteal progesterone release in vitro was also greater between Days 14 and 16 than at any other time. Incubation of luteal tissue at $0^{\circ} \mathrm{C}$ significantly reduced progesterone release in vitro when compared with incubation at $37^{\circ} \mathrm{C}$ on Days 8,12 and $14(P<0.05)$, but not on Days 16 and 18 . The presence of indomethacin during incubation at $37^{\circ} \mathrm{C}$ had no significant effect on progesterone release at $37^{\circ} \mathrm{C}$ for any day of the cycle.

Table 1. Plasma progesterone and progesterone released in vitro during a 2-h incubation period from luteal tissue of pigs on various days of the oestrous cycle

\begin{tabular}{|c|c|c|c|c|}
\hline \multirow[b]{2}{*}{$\begin{array}{l}\text { Day of } \\
\text { cycle }\end{array}$} & \multirow{2}{*}{$\begin{array}{c}\text { Plasma } \\
\text { progesterone } \\
(\mathrm{ng} / \mathrm{ml})\end{array}$} & \multicolumn{3}{|c|}{ Progesterone (ng/mg tissue) } \\
\hline & & $0^{\circ} \mathrm{C}$ & $37^{\circ} \mathrm{C}$ & $\begin{array}{c}37^{\circ} \mathrm{C}+ \\
\text { indomethacin }\end{array}$ \\
\hline 8 & $25 \cdot 1 \pm 1.9^{\mathrm{a}}$ & $2 \cdot 5 \pm 0.4^{\mathrm{a}}$ & $18 \cdot 0 \pm 4 \cdot 6^{a}$ & $14 \cdot 1 \pm 2 \cdot 7^{\mathrm{a}}$ \\
\hline 12 & $42 \cdot 8 \pm 4 \cdot 2^{\mathrm{b}}$ & $3.6 \pm 0.5^{b}$ & $12 \cdot 6 \pm 2 \cdot 2^{\mathrm{ab}}$ & $12 \cdot 1 \pm 2 \cdot 6^{\mathrm{ab}}$ \\
\hline 14 & $36.3 \pm 2.9^{\mathrm{ab}}$ & $3.0 \pm 0.4^{\mathrm{ab}}$ & $9.4 \pm 1.8^{\mathrm{bc}}$ & $7 \cdot 3 \pm 1 \cdot 1^{\mathrm{bc}}$ \\
\hline 16 & $5 \cdot 9 \pm 3 \cdot 1^{c}$ & $0.8 \pm 0.2^{\mathrm{c}}$ & $2 \cdot 7 \pm 0 \cdot 8^{c}$ & $2.9 \pm 0.9^{c}$ \\
\hline 18 & $4 \cdot 5 \pm 3 \cdot 4^{c}$ & $0.6 \pm 0.4^{c}$ & $2 \cdot 5 \pm 1 \cdot 6^{\mathrm{c}}$ & $2 \cdot 7 \pm 1 \cdot 5^{c}$ \\
\hline
\end{tabular}

Values are mean \pm s.e.m. for 6 observations/group.

Means within a column with no superscript letter in common differ significantly by Duncan's Multiple Range Test $(P<0.05)$.

Means for endometrial and luteal PGF release in vitro are shown in Table 2. Endometrial PGF release in vitro at $37^{\circ} \mathrm{C}$ increased from Day 8 to the highest value on Day 16, the mean for Day 16 being significantly greater than those for the preceding days $(P<0.05)$. Luteal PGF release in vitro at $37^{\circ} \mathrm{C}$ increased after Day 14, but only the means for Days 8 and 18 differed significantly $(P<0.05)$. Incubation of endometrial or luteal tissue at $0^{\circ} \mathrm{C}$ or at $37^{\circ} \mathrm{C}$ plus indomethacin reduced PGF release on all days of the cycle sampled $(P<0.01)$.

Two pigs, one each on Days 16 and 18 , had active corpora lutea as indicated by high plasma progesterone values of 21.2 and $21.3 \mathrm{ng} / \mathrm{ml}$ on Days 16 and 18 , respectively. The hormone values from these 2 pigs were included in the statistical analyses and in data represented in Tables 1-4 and Text-fig. 1. Endometrial PGF release in vitro for these 2 pigs with active corpora lutea was low on Days 16 and $18(13.0$ and $7.5 \mathrm{ng} / 100 \mathrm{mg}$ tissue, respectively).

The means for plasma progesterone and release of progesterone and PGF in vitro at $37^{\circ} \mathrm{C}$ were plotted in Text-fig. 1 to show their temporal relationships. Calculation of the simple linear 
Table 2. Release of PGF in vitro during a 2-h incubation period from endometrial and luteal tissues of pigs on various days of the oestrous cycle

\begin{tabular}{|c|c|c|c|c|c|c|}
\hline \multirow[b]{2}{*}{$\begin{array}{l}\text { Day of } \\
\text { cycle }\end{array}$} & \multicolumn{3}{|c|}{ Endometrial PGF (ng/100 mg tissue) } & \multicolumn{3}{|c|}{ Luteal PGF (ng/100 mg tissue) } \\
\hline & $0^{\circ} \mathrm{C}$ & $37^{\circ} \mathrm{C}$ & $\begin{array}{c}37^{\circ} \mathrm{C}+ \\
\text { indomethacin }\end{array}$ & $0^{\circ} \mathrm{C}$ & $37^{\circ} \mathrm{C}$ & $\begin{array}{c}37^{\circ} \mathrm{C}+ \\
\text { indomethacin }\end{array}$ \\
\hline 8 & $4.8 \pm 0.8^{a}$ & $22 \cdot 4 \pm 4 \cdot 0^{\mathrm{a}}$ & $7.9 \pm 1.0^{\mathrm{a}}$ & $6.3 \pm 1.8^{a}$ & $18.5 \pm 2.6^{a}$ & $10 \cdot 0 \pm 1 \cdot 5^{\mathrm{a}}$ \\
\hline 12 & $6 \cdot 1 \pm 1 \cdot 6^{\mathrm{a}}$ & $28.2 \pm 6.5^{\mathrm{ab}}$ & $7 \cdot 6 \pm 1.0^{\mathrm{a}}$ & $3 \cdot 9 \pm 0.9^{a}$ & $20 \cdot 9 \pm 2 \cdot 6^{\mathrm{ab}}$ & $9.2 \pm 0.7^{\mathrm{a}}$ \\
\hline 14 & $7.6 \pm 1.8^{\mathrm{a}}$ & $43 \cdot 7 \pm 11 \cdot 2^{\mathrm{ab}}$ & $14.5 \pm 1.9^{\mathrm{a}}$ & $5 \cdot 9 \pm 1 \cdot 3^{\mathrm{a}}$ & $20.8 \pm 1.9^{\mathrm{ab}}$ & $9.6 \pm 1.6^{\mathrm{a}}$ \\
\hline 16 & $18.9 \pm 7.2^{b}$ & $103 \cdot 5 \pm 28 \cdot 6^{c}$ & $28 \cdot 3 \pm 7 \cdot 2^{b}$ & $5 \cdot 3 \pm 1 \cdot 2^{\mathrm{a}}$ & $33 \cdot 3 \pm 6 \cdot 5^{\mathrm{ab}}$ & $13.5 \pm 1.8^{\mathrm{a}}$ \\
\hline 18 & $9.0 \pm 1.7^{\mathrm{ab}}$ & $80 \cdot 2 \pm 21.5^{b c}$ & $16 \cdot 6 \pm 3 \cdot 1^{\mathrm{a}}$ & $7 \cdot 2 \pm 1.8^{a}$ & $37.8 \pm 10 \cdot 3^{\mathrm{b}}$ & $14 \cdot 0 \pm 3 \cdot 3^{\mathrm{a}}$ \\
\hline
\end{tabular}

Values are mean \pm s.e.m. for 6 observations/group.

Means within a column with no superscript letter in common differ significantly by Duncan's Multiple Range Test $(P<0.05)$.

Table 3. Simple correlations for 30 observations for plasma progesterone and release in vitro at $37^{\circ} \mathrm{C}$ for progesterone and PGF

\begin{tabular}{llcccc}
\hline & & \multicolumn{3}{c}{ Variables } \\
\cline { 2 - 5 } \multicolumn{1}{c}{ Variables } & & $\begin{array}{c}\text { Luteal } \\
\text { progesterone }\end{array}$ & $\begin{array}{c}\text { Luteal } \\
\text { PGF }\end{array}$ & $\begin{array}{c}\text { Endometrial } \\
\text { PGF }\end{array}$ & $\begin{array}{c}\text { Day of } \\
\text { the cycle }\end{array}$ \\
\hline Plasma progesterone & $r$ & 0.512 & -0.489 & -0.487 & -0.547 \\
& $P$ & 0.004 & 0.007 & 0.007 & 0.0018 \\
Luteal progesterone & $r$ & & -0.472 & -0.533 & -0.700 \\
& $P$ & & 0.0085 & 0.0024 & 0.0001 \\
Luteal PGF & $r$ & & & 0.278 & 0.455 \\
& $P$ & & & 0.135 & 0.0115 \\
Endometrial PGF & $r$ & & & & 0.527 \\
& $P$ & & & & 0.0028 \\
\hline
\end{tabular}

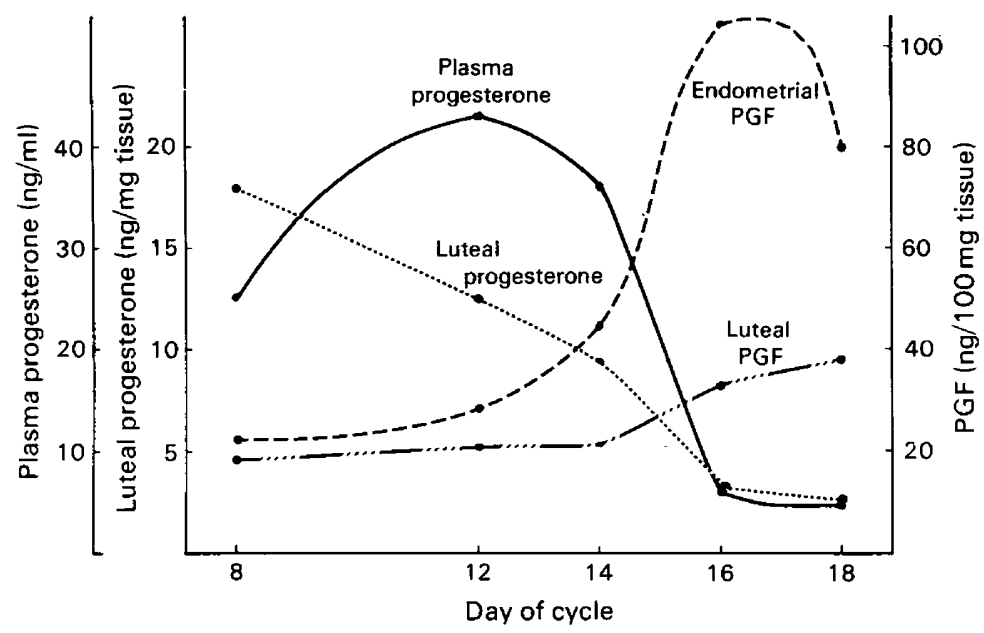

Text-fig. 1. Temporal relationships of plasma progesterone and release in vitro at $37^{\circ} \mathrm{C}$ of luteal progesterone and luteal and endometrial PGF during the oestrous cycle of the pig. 
correlation coefficients (Table 3) showed that plasma progesterone and luteal progesterone release in vitro were negatively correlated with luteal and endometrial PGF release in vitro. However, when the effect of day of the cycle was eliminated, the partial correlation coefficients for luteal progesterone release in vitro with PGF release in vitro were not significant for either luteal or endometrial tissue (Table 4). Plasma progesterone retained a negative correlation with endometrial PGF release in vitro but not with luteal PGF release in vitro. Luteal and endometrial PGF release in vitro were not significantly correlated.

Table 4. Partial correlations for 24 observations for plasma progesterone and release in vitro at $37^{\circ} \mathrm{C}$ for progesterone and PGF when day of the cycle is held constant

\begin{tabular}{llccc}
\hline & & \multicolumn{3}{c}{ Variables } \\
\cline { 2 - 5 } \multicolumn{1}{c}{ Variables } & & Luteal & Luteal & Endometrial \\
& & progesterone & PGF & PGF \\
\hline Plasma progesterone & $r$ & 0.438 & -0.214 & -0.396 \\
& $P$ & 0.025 & 0.290 & 0.045 \\
Luteal progesterone & $r$ & & -0.220 & -0.201 \\
& $P$ & & 0.280 & 0.330 \\
Luteal PGF & $r$ & & & -0.027 \\
& $P$ & & & 0.910 \\
\hline
\end{tabular}

\section{Discussion}

Accumulation of endometrial PGF in the incubation medium may be an index of the intrinsic potential of the endometrium to synthesize PGF- $2 \alpha$ in vivo. Endometrial PGF release in vitro increased from Day 12 to Day 16 of the oestrous cycle in conjunction with a decrease in plasma progesterone during the same time interval. Release of endometrial PGF in vitro was also reported to be higher in the late luteal phase, Days 14-15, than in any other stage of the cycle in guinea-pigs (Poyser, 1972) and ewes (Patek \& Watson, 1976b; Roberts, McCracken, Gavagan \& Soloff, 1976); the increased release of PGF coincided with the time of luteolysis.

In an earlier experiment (Guthrie et al., 1978), we found that endometrial synthesis of PGF in vitro was greater on Days 15-16 of the cycle than on Days 7-8 although the difference was not statistically significant. Plasma progesterone averaged $11.2 \mathrm{ng} / \mathrm{ml}$ on Days $15-16$, indicating that luteolysis had not proceeded to the degree found in the present experiment. In our present experiment, the highest level of endometrial PGF release coincided with very low plasma progesterone and progesterone release in vitro. In the pig (Gleeson et al., 1974; Killian et al., 1976; Moeljono et al., 1977) and ewe (Cox, Thorburn, Currie, Restall \& Schneider, 1972), PGF secretion, i.e. concentrations in the utero-ovarian vein, generally increased gradually after Day 12, but the fact that quite large amounts of PGF were secreted periodically after plasma progesterone values had fallen to very low levels indicates maximum synthesis of endometrial PGF- $2 \alpha$ in vivo after luteolysis was almost completed. Thus, the decrease in plasma progesterone, resulting from early PGF- $2 \alpha$ secretion and perhaps increased oestradiol secretion, may facilitate the increased secretion of endometrial PGF-2 $\alpha$ in the pig as has been reported for the ewe (Scaramuzzi, Baird, Boyle, Land \& Wheeler, 1977).

The pattern of progesterone release in vitro appears to differ from that of the secretion of progesterone in vivo into peripheral plasma (Text-fig. 1). However, this apparent difference in secretion patterns may have limited significance. The means for progesterone secretion in vitro on Days 8 and 12 did not differ significantly, and the variation between animals within days can be high. In addition, progesterone concentrations in plasma from the peripheral circulation or 
ovarian vein differ among pigs, and reports differ with respect to which day of the cycle the progesterone secretion rate is highest (Masuda, Anderson, Henricks \& Melampy, 1967; Brinkley \& Young, 1968; Henricks, Guthrie \& Handlin, 1972).

Whether luteal PGF-2 $\alpha$ synthesis has a role in the uterine luteolytic process is still not clear. Patek \& Watson (1976a) indicated that both endometrial and luteal PGF release in vitro were higher during the late luteal phase of the cycle than at any other time. However, their conclusion was apparently derived without appropriate statistical analysis of the data, and they estimated the day of the cycle by the morphological appearance of the corpora lutea in ovaries recovered from pigs slaughtered at an abattoir. When we consider the difficulty in dating pig corpora lutea by their morphological appearance (Masuda et al., 1967), an error of $48 \mathrm{~h}$ in dating would not be unexpected. The results of our study do not support the proposal (Patek \& Watson, 1976a) of a role for luteal PGF-2 $\alpha$ secretion in the process of luteolysis initiated by the uterus. Endometrial PGF release in vitro was not significantly correlated with luteal PGF release in vitro. We detected an increase in the mean luteal PGF release in vitro from Days 14 to 16 , but the increase was not consistent enough to be significant. In addition, when corrected for the effect of day of the cycle, luteal PGF release in vitro was not correlated with plasma progesterone or luteal progesterone release in vitro. In contrast, we have shown that increased luteal PGF release in vitro (Guthrie, Rexroad \& Bolt, 1979) was associated with luteolysis induced by the PGF-2 $\alpha$ analogue, Cloprostenol (ICI-80,996). We have not determined whether increased PGF release from pig luteal tissue in vitro was an artefact of induced luteolysis or a step in the process of induced luteolysis.

The evidence that PGF- $2 \alpha$ is the natural luteolysin in the pig is not conclusive. Watson \& Maule Walker (1977) reported that endometrial superfusates from the late luteal phase of the cycle decreased luteal progesterone secretion in vitro by $90 \%$. The luteolyic effects of the endometrial superfusate did not appear to be due to PGF- $2 \alpha$ release by endometrial or luteal tissue. More work is required to determine which factors originating in the uterine endometrium, besides PGF-2 $\alpha$, may be luteolytic in the pig and to what degree, if any, luteal PGF-2 $\alpha$ synthesis is involved in luteolysis.

We thank Kathy Ogle and Ann Powell for technical assistance and Linda Neuenhahn for typing this manuscript.

Mention of a trade name, specific product, or equipment does not constitute a guarantee or warranty by the U.S. Department of Agriculture and does not imply its approval to the exclusion of other products that may be suitable.

\section{References}

Anderson, L.L., Butcher, R.L. \& Melampy, R.M. (1963) Uterus and the occurrence of oestrus in pigs. Nature, Lond. 198, 311-312.

Brinkley, H.J. \& Young, E.P. (1968) Determination of the in vivo rate of progesterone secretion by the ovary of the pig during the luteal phase of the estrous cycle. Endocrinology 82, 203-208.

Cox, R.I., Thorburn, G.D., Currie, W.B., Restall, B.J. \& Schneider, W. (1972) Prostaglandin F group (PGF), progesterone, and estrogen concentrations in the uteroovarian venous plasma of the conscious ewe during the estrous cycle. $A d v$. Biosci. 9, 625-630.

Gleeson, A.R. (1974) Luteal function in the cyclic sow after infusion of prostaglandin F-2 $\alpha$ through a uterine vein. J. Reprod. Fert. 36, 487-488.
Gleeson, A.R., Thorburn, G.D. \& Cox, R.I. (1974) Prostaglandin $\mathrm{F}$ concentrations in the uteroovarian venous plasma of the sow during the late luteal phase of the oestrous cycle. Prostaglandins 5, 521-529.

Guthrie, H.D. (1977) Induction of ovulation and fertility in prepuberal gilts. J. Anim. Sci. 45, 1360-1367.

Guthrie, H.D. \& Polge, C. (1976) Luteal function and oestrus in gilts treated with a synthetic analogue of prostaglandin F-2 $\alpha$ (ICI 79,939) at various times during the oestrous cycle. J. Reprod. Fert. 48, 423-425.

Guthrie, H.D. \& Polge, C. (1978) Treatment of pregnant gilts with a prostaglandin analogue, cloprostenol, to control oestrus and fertility. J. Reprod. Fert. 52, $271-273$. 
Guthrie, H.D., Rexroad, C.E., Jr \& Bolt, D.J. (1978) In vitro synthesis of progesterone and prostaglandin $F$ by luteal tissue and prostaglandin $F$ by endometrial tissue from the pig. Prostaglandins 16, 433-440.

Guthrie, H.D., Rexroad, C.E., Jr \& Bolt, D.J. (1979) In vitro release of progesterone and prostaglandins $\mathbf{F}$ and $E$ by porcine luteal and endometrial tissue during induced luteolysis. In Ovarian Follicular and Corpus Luteum Function, pp. 627-632. Eds C. P. Channing, J. M. Marsh \& W. A. Sadler. Plenum, New York.

Hallford, D.M., Wettemann, R.P., Turman, E.J. \& Omtvedt, I.T. (1975) Luteal function in gilts after prostaglandin F-2a. J. Anim. Sci. 41, 1706-1710.

Henricks, D.M., Guthrie, H.D. \& Handlin, D.L. (1972) Plasma estrogen, progesterone, and luteinizing hormone levels during the estrous cycle in pigs. Biol. Reprod. 6, 210-218.

Killian, D.B., Davis, D.L. \& Day, B.N. (1976) Plasma PGF and hormonal changes during the estrous cycle and early pregnancy in the gilt. Proc. Int. Pig Vet. Soc. Congr. D 1.

Masuda, H., Anderson, L.L., Henricks, D.M. \& Melampy, R.M. (1967) Progesterone in ovarian venous plasma and corpora lutea of the pig. Endocrinology 80, 240-245.

Moeljono, M.P.E., Thatcher, W.W., Bazer, F.W., Frank, M., Owens, L.J. \& Wilcox, C.J. (1977) A study of prostaglandin $F_{2} \alpha$ as the luteolysin in swine. II. Characterization and comparison of prostaglandin $F$, estrogens and progestin concentrations in utero- ovarian vein plasma of nonpregnant and pregnant gilts. Prostaglandins 14, 543-555.

Patek, C.E. \& Watson, J. (1976a) Prostaglandin F and progesterone secretion by porcine endometrium and corpus luteum in vitro. Prostaglandins 12, 97-111.

Patek, C.E. \& Watson, J. (1976b) Prostaglandin production during the oestrous cycle by porcine and ovine corpus luteum tissue in vitro. $J$. Endocr. 71, $47 P-48 P$.

Poyser, N.L. (1972) The formation of prostaglandins by the guinea-pig uterus and the effect of indomethacin. Adv. Biosci. 9, 631-634.

Rexroad, C.E., Jr (1978) Cycloheximide blockage of estradiol-17 $\beta$-induced contractions in ovariectomized ewes. Biol. Reprod. 19, 648-652.

Roberts, J.S., McCracken, J.A., Gavagan, J.E. \& Soloff, M.S. (1976) Oxytocin-stimulated release of prostaglandin F-2 $\alpha$ from ovine endometrium in vitro: correlation with estrous cycle and oxytocin-receptor binding. Endocrinology 99, 1107-1114.

Scaramuzzi, R.J., Baird, D.T., Boyle, H.P., Land, R.B. \& Wheeler, A.G. (1977) The secretion of prostaglandin $F$ from the autotransplanted uterus of the ewe. $J$. Reprod. Fert. 49, 157-160.

Snedecor, G.W. \& Cochran, W.G. (1967) Statistical Methods, 6th edn. Iowa State University Press, Ames.

Watson, J. \& Maule Walker, F.M. (1977) Effect of prostaglandin F-2 $\alpha$ and uterine extracts on progesterone secretion in vitro by superfused pig corpora lutea. J. Reprod. Fert. 51, 393-398.

Received 13 December 1979 